\title{
APPLICATION OF BRASSINOSTEROID TO Tabebuia alba (BIGNONIACEAE) PLANTS
}

\author{
ELIZABETH ORIKA ONO ${ }^{1}$, TERUKO NAKAMURA ${ }^{2}$, SÍLVIA RODRIGUES \\ MACHADO $^{1}$ AND JOÃO DOMINGOS RODRIGUES ${ }^{1}$
}

\begin{abstract}
Department of Botany, Institute of Biosciences, São Paulo University and ${ }^{2}$ Laboratory of Plant Physiology, Faculty of Science, Japan Women's University, Tokyo, Japan.
\end{abstract}

\begin{abstract}
The objective of this study was to observe the effects of brassinosteroid, gibberelin, and auxin application on the development and foliar anatomy of Tabebuia alba (Cham.) Sandw. seedlings. T. alba seedlings were grown in plastic bags with fertilized soil and treated with the following: 1- water (control); 2brassinolide $\left(\mathrm{BR}_{1}\right) 0.104 \mathrm{mM}$; 3- $\mathrm{BR}_{1} 0.208 \mathrm{mM}$; 4- 3-indoleacetic acid (IAA) $0.2854 \mathrm{mM}$; 5- IAA 0.5708

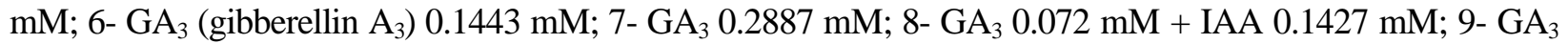
$0.1443 \mathrm{mM}+\mathrm{IAA} 0.2854 \mathrm{mM} ; 10-\mathrm{GA}_{3} 0.072 \mathrm{mM}+\mathrm{BR}_{1} 0.052 \mathrm{mM}$; and $11-\mathrm{GA}_{3} 0.1443 \mathrm{mM}+\mathrm{BR}_{1} 0.104$ $\mathrm{mM}$. Plant height and petiole length were measured before the treatments and 21 days after application of the growth regulators. These data allowed the calculation of stem and petiole growth rates. The results showed that $\mathrm{GA}_{3}+$ brassinolide produced the highest stem and petiole growth rates and brassinolide application stimulated petiole growth but not stem growth. The anatomical study of leaves showed alterations in blade and petiole thickness, palisade and spongy parenchyma height, and epidermis cells.
\end{abstract}

ADITIONAL INDEX TERMS: Tabebuia alba L., brassinosteroids, GA, auxin, growth.

\section{APLICAÇÃO DE BRASSINOESTERÓIDE EM PLANTAS DE IPÊ (Tabebuia alba)}

RESUMO - O objetivo deste estudo foi de se verificar o efeito da aplicação de brassinoesteróide, giberelina e auxina no desenvolvimento e anatomia foliar de plantulas jovens de Tabebuia alba (Cham.) Sandw. Para tanto, utilizaram-se plântulas de ipê de 104 dias cultivadas em saco plástico com capacidade para 1 litro contendo solo adubado. Os tratamentos aplicados via pulverização foliar foram: 1 - água, 2 brassinólide $\left(\mathrm{BR}_{1}\right)$ 0,104 mM, 3 - $\mathrm{BR}_{1}$ 0,208mM, 4 - ácido indolil-3-acético (IAA) 0,285mM, 5 - IAA 0,5708mM, $6-\mathrm{GA}_{3}$ (ácido giberélico) $0,1443 \mathrm{mM}, 7-\mathrm{GA}_{3} 0,2887 \mathrm{mM}, 8-\mathrm{GA}_{3} 0,072 \mathrm{mM}+$ IAA $0,1427 \mathrm{mM}, 9-\mathrm{GA}_{3} 0,1443 \mathrm{mM}+\mathrm{IAA} \quad 0,285 \mathrm{mM}, 10-\mathrm{GA}_{3} 0,072 \mathrm{mM}+\mathrm{BR} 10,052 \mathrm{mM}$ e $11-\mathrm{GA}_{3}$ $0,1443 \mathrm{nM}+\mathrm{BR} 10,208 \mathrm{mM}$. As seguintes observações foram realizadas antes da aplicação dos tratamentos e 21 dias após: altura da planta e comprimento do pecíolo. Com base nesses dados, foi calculada a taxa de crescimento do caule e do pecíolo. Pelos resultados, constatou-se que a aplicação de brassinólide estimula o crescimento do pecíolo, mas não do caule. Os estudos anatômicos das folhas mostraram alterações na espessura do limbo e pecíolo, na altura do parênquima paliçádico e lacunoso e nas células da epiderme.

TERMOS ADICIONAIS PARA INDEXAÇÃO: Tabebuia alba L., brassinoesteróides, GA, auxina, crescimento.

Received: 10/12/99 - Accepted: 03/11/2000

1. Department of Botany, Institute of Biosciences, São Paulo University

2. Laboratory of Plant Physiology, Faculty of Science, Japan Women's University, Tokyo, Japan. 


\section{INTRODUCTION}

Brassinosteroids are steroids that occur in many plant species with common biological activities, suggesting that they are a new group of plant growth hormones (Yokota and Takahashi, 1985). These hormones affect several biological processes, including stem elongation, pollen tube growth, leaf bending, root growth, and xylem formation (Yokota, 1997). These developmental activities are mainly associated with ATPase activity (Cerana et al., 1983), synthesis of 1aminocyclopropane-1-carboxylic acid synthase (Arteca et al., 1983), alteration in microtubule orientation (Mayumi and Shibaoka, 1995), and modification of cell walls (Zurek et al., 1994).

Clouse and Zurek (1991) observed that exogenously supplied brassinolide, the most active brassinosteroid, promoted both tracheary element differentiation and cell division in cultured tuber explants. Iwasaki and Shibaoka (1991) also reported that brassinosteroids produced parenchyma cell differentiation into tracheary elements.

Brassinosteroids are known to act synergistically with auxin to stimulate cell elongation (Katsumi, 1985; Sasse, 1990) and ethylene production (Arteca et al., 1983), suggesting that their effects are mediated by auxin (Takeno and Pharis, 1982) or that brassinosteroids enhance tissue sensitivity to auxin (Mandava, 1988). Despite indirect evidence that the mode of action of brassinosteroids is different from that of auxin (Katsumi, 1991), there are indications that brassinosteroids may somehow influence the endogenous auxin content. The increase in auxin content in plant cells both after its exogenous application and biosynthetic gene expression was followed by a significant decrease in cytokinin levels or an increase in cytokinin degradation in transformed tobacco plants (Vanková et al., 1991, 1992). Thus brassinosteroids lead to changes in auxin/cytokinin ratio in plant tissues.

Some studies have been performed on woody plants to evaluate the effect of brassinosteroid application. The objective of this study was to observe the effects of application of brassinosteroid alone or in combination with gibberellin or auxin on the development and foliar anatomy of Tabebuia alba (Cham.) Sandw plants.

\section{MATERIALS AND METHODS}

This study was performed at the Department of Botany, Institute of Biosciences, São Paulo State University - UNESP, in a fiberglass-covered greenhouse with automated heating and cooling systems at $25^{\circ} \mathrm{C}$.

Tabebuia alba (Cham.) Sandw. seedlings (104 days old) were obtained from seeds germinated in laboratory conditions. These were planted in plastic bags containing fertilized soil. The plants received the following treatments: 1water (control); 2- brassinolide $\left(\mathrm{BR}_{1}\right) 0.104 \mathrm{mM}$; 3- $\mathrm{BR}_{1} 0.208 \mathrm{mM}$; 4- 3-indoleacetic acid (IAA) $0.2854 \mathrm{mM}$; 5- IAA $0.5708 \mathrm{mM} ; 6-\mathrm{GA}_{3}$ (gibberellin $\mathrm{A}_{3}$ ) $0.1443 \mathrm{mM} ; 7-\mathrm{GA}_{3} 0.2887 \mathrm{mM}$; 8- $\mathrm{GA}_{3} 0.072 \mathrm{mM}$ + IAA $0.1427 \mathrm{mM}$; 9- $\mathrm{GA}_{3}$ $0.1443 \mathrm{mM}$ + IAA $0.2854 \mathrm{mM} ; 10-\mathrm{GA}_{3} 0.072$ $\mathrm{mM}+\mathrm{BR}_{1} 0.052 \mathrm{mM}$; and 11- $\mathrm{GA}_{3} 0.1443 \mathrm{mM}+$ $\mathrm{BR}_{1} 0.104 \mathrm{mM}$.

Treatments were applied once with a manual sprayer, and 4 plants from each treatment were sprayed with $50 \mathrm{~mL}$ of each solution.

The following observations were made before the treatments and 21 days after application in order to evaluate the effects of auxin, gibberellin, and brassinoesteroid on plant development:

a) Stem height was considered as the length from the ground surface up to the shoot apex, measured with a ruler; and

b) Petiole length of the apical mature leaf was measured with a caliper.

These data allowed the estimation of stem and petiole growth.

The results obtained were submitted to analysis of variance (F test). Means were compared by the Tukey test at $5 \%$ significance level.

Twenty-one days after the treatments, anatomical analyses were undertaken on the petiole and blade median zones of completely expanded leaves. These samples were fixed with Karnovsky's solution (Karnovsky, 1985) for $24 \mathrm{~h}$, 
dehydrated in alcoholic series, and included in glycol-methacrylate (Ruetze and Schmitt, 1986). The $6 \mathrm{~mm}$-thick sections were stained with $0.05 \%$ Toluidine blue, pH 4.7 (Feder and O'Brien, 1968) and mounted with Permount.

\section{RESULTS AND DISCUSSION}

Tables 1 and 2 show the effect of IAA, $\mathrm{GA}_{3}, \mathrm{BR}_{1}, \mathrm{GA}_{3}+\mathrm{IAA}$ and $\mathrm{GA}_{3}+\mathrm{BR}_{1}$ application on the petiole $(\mathrm{F}=5.89)$ and stem $(\mathrm{F}=6.44)$ growth of Tabebuia alba seedlings. Table 1 shows that treatment of $T$. alba plants with the two concentrations of $\mathrm{BR}_{1}$ did not significantly affect petiole growth. However, $\mathrm{BR}_{1}$ at $100 \mathrm{mg} . \mathrm{L}^{-1}$ induced a small increase in petiole growth when compared to the control. Treatment of $T$. alba seedlings with IAA at 0.2854 and $0.5708 \mathrm{mM}$ and $\mathrm{GA}_{3}$ at $0.2887 \mathrm{mM}$ induced similar results to the control. The application of $\mathrm{GA}_{3}$ at $0.1443 \mathrm{mM}$ produced a small increase in $T$. alba petiole growth. When $\mathrm{GA}_{3}$ application was followed by that of IAA at the tested concentrations, there was no positive interaction between these two plant growth regulators in relation to petiole growth, rather, an antagonistic interaction was observed or $\mathrm{GA}_{3}$ and IAA act independently on petiole growth. Application of $\mathrm{GA}_{3}$ followed by $\mathrm{BR}_{1}$ at $0.104 \mathrm{mM}$ showed a positive interaction on petiole growth, whereas $\mathrm{GA}_{3}$ and $\mathrm{BR}_{1}$ had a synergistic effect. These results also suggest that $\mathrm{BR}_{1}$ alone had little effect on petiole growth, but the combination of $\mathrm{BR}_{1}$ with $\mathrm{GA}_{3}$ increased petiole growth.

TABLE 1 - Petiole growth rate of Tabebuia alba seedlings 21 days after application of the growth regulators.

\begin{tabular}{lc}
\hline \multicolumn{1}{c}{ Treatments } & $\begin{array}{c}\text { Petiole growth rate } \\
\left(\mathrm{mm} \mathrm{day}^{-1}\right)\end{array}$ \\
\hline Control & $5 \times 10^{-2} \mathrm{~b}$ \\
$\mathrm{BR}_{1} 0.104 \mathrm{mM}$ & $9 \times 10^{-2} \mathrm{~b}$ \\
$\mathrm{BR}_{1} 0.208 \mathrm{mM}$ & $14 \times 10^{-2} \mathrm{~b}$ \\
$\mathrm{IAA} 0.2854 \mathrm{mM}$ & $4 \times 10^{-2} \mathrm{~b}$ \\
$\mathrm{IAA}^{0} 0.5708 \mathrm{mM}$ & $5 \times 10^{-2} \mathrm{~b}$ \\
$\mathrm{GA}_{3} 0.1443 \mathrm{mM}$ & $17 \times 10^{-2} \mathrm{ab}$ \\
$\mathrm{GA}_{3} 0.2887 \mathrm{mM}$ & $4 \times 10^{-2} \mathrm{~b}$ \\
$\mathrm{GA}_{3} 0.072 \mathrm{mM}+\mathrm{IAA}_{0.0 .1427 \mathrm{mM}}$ & $8 \times 10^{-2} \mathrm{~b}$ \\
$\mathrm{GA}_{3} 0.1443 \mathrm{mM}+\mathrm{IAA}^{0.2854 \mathrm{mM}}$ & $9 \times 10^{-2} \mathrm{~b}$ \\
$\mathrm{GA}_{3} 0.072 \mathrm{mM}+\mathrm{BR}_{1} 0.052 \mathrm{mM}$ & $24 \times 10^{-2} \mathrm{ab}$ \\
$\mathrm{GA}_{3} 0.1443 \mathrm{mM}+\mathrm{BR}_{1} 0.104 \mathrm{mM}$ & $39 \times 10^{-2} \mathrm{a}$ \\
\hline
\end{tabular}

Averages followed by the same letter are not significantly different according to the Tukey test $(\mathrm{p} \leq 0.05)$.

R. Bras. Fisiol. Veg., 12(3):187-194, 2000 
TABLE 2 - Stem growth rate of Tabebuia alba seedlings 21 days after application of the growth regulators.

\begin{tabular}{lc}
\hline \multicolumn{1}{c}{ Treatments } & $\begin{array}{c}\text { Stem growth rate } \\
\left(\mathrm{mm} \mathrm{day}^{-1}\right)\end{array}$ \\
\hline Control & $0.26 \mathrm{c}$ \\
$\mathrm{BR}_{1} 0.104 \mathrm{mM}$ & $0.39 \mathrm{c}$ \\
$\mathrm{BR}_{1} 0.208 \mathrm{mM}$ & $0.37 \mathrm{c}$ \\
$\mathrm{IAA} 0.2854 \mathrm{mM}$ & $0.40 \mathrm{bc}$ \\
$\mathrm{IAA} 0.5708 \mathrm{mM}$ & $0.25 \mathrm{c}$ \\
$\mathrm{GA}_{3} 0.1443 \mathrm{mM}$ & $2.45 \mathrm{abc}$ \\
$\mathrm{GA}_{3} 0.2887 \mathrm{mM}$ & $2.25 \mathrm{abc}$ \\
$\mathrm{GA}_{3} 0.072 \mathrm{mM}+\mathrm{IAA}_{0.1427 \mathrm{mM}}$ & $0.39 \mathrm{c}$ \\
$\mathrm{GA}_{3} 0.1443 \mathrm{mM}+\mathrm{IAA}_{0.2854 \mathrm{mM}}$ & $2.84 \mathrm{a}$ \\
$\mathrm{GA}_{3} 0.072 \mathrm{mM}+\mathrm{BR}_{1} 0.052 \mathrm{mM}$ & $2.99 \mathrm{a}$ \\
$\mathrm{GA}_{3} 0.1443 \mathrm{mM}+\mathrm{BR}_{1} 0.104 \mathrm{mM}$ & $2.75 \mathrm{ab}$ \\
\hline
\end{tabular}

Averages followed by the same letter are not significantly different according to the Tukey test ( $\mathrm{p} \leq 0.05)$.

The application of $\mathrm{BR}_{1}$ and IAA at the two concentrations did not cause stem growth in $T$. alba seedlings (Table 2). However the application of $\mathrm{GA}_{3}$ at 0.1443 and $0.2887 \mathrm{mM}$ significantly increase stem growth. The use $\mathrm{GA}_{3}$ at $0.1443 \mathrm{mM}$ followed by IAA at $0.2854 \mathrm{mM}$ caused the highest increase in stem growth, showing a positive or synergistic interaction between IAA and $\mathrm{GA}_{3}$, or a synergistic at a higher concentration. The interaction between $\mathrm{GA}_{3}$ at $0.1443 \mathrm{mM}$ and $\mathrm{BR}_{1}$ at 0.052 and $0.104 \mathrm{mM}$ was positive. This interaction led to a significant increase in stem growth of $T$. alba seedlings, when compared with each plant growth regulator used alone.

$\mathrm{Xu}$ et al. (1995), studying the link between plant growth substances and the $\mathrm{TCH} 4$ gene expression, found that auxin and brassinosteroid stimulated $\mathrm{TCH} 4$ expression, increasing TCH4 MRNA levels that encode an xyloglucan endotransglycosylase (XET). They also observed that $\mathrm{GA}_{3}$, benzyladenine (cytokinin), and 1-aminocyclopropane-1-carboxylic acid (ACC) had no detectable effect on TCH4 expression. However, Potter and Fry (1994) and Smith et al. (1996) observed a GA-stimulated growth and XET activity in many tissues. Xu et al. (1995) suggested that no relationship was seen between the effects of auxins on cell elongation and XET activity, but endogenous IAA (3-indoleacetic acid) stimulated TCH4 gene expression.

The results of this study showed that $\mathrm{GA}_{3}$ and $\mathrm{BR}_{1}$ stimulated petiole and stem growth in Tabebuia alba seedlings, mainly when applied in sequence. Literature reports suggest that $\mathrm{BR}_{1}$ stimulates $\mathrm{TCH} 4$ gene expression leading to the production of XET MRNA and promoting growth. Also, $\mathrm{GA}_{3}$ stimulates enzyme activity, suggesting that $\mathrm{GA}_{3}$ and $\mathrm{BR}_{1}$ can be additive on petiole and stem growth, each complementing the effect of the other.

IAA application on $T$. alba seedlings showed a positive interaction with $\mathrm{GA}_{3}$ on stem growth. It can be suggested that the interaction between $\mathrm{GA}_{3}$ and IAA, and $\mathrm{GA}_{3}$ and $\mathrm{BR}_{1}$ is 
important for stem growth, since, according to the literature, $\mathrm{GA}_{3}$ stimulates XET activity and IAA and brassinolide stimulates TCH4 gene expression.

Anatomical analysis transverse sections of the leaf blade showed that treatments with brassinosteroids alone (Figure 1B and 1C) or in combination with $\mathrm{GA}_{3}$ (Figure $1 \mathrm{D}$ and $1 \mathrm{E}$ ) produced a generalized increase in epidermis size and mesophyll cells, when compared to the control plants (Figure 1A). Table 3 shows the effects of the treatments on the thickness of leaf blade and length of constituent cells. A significant increase could be observed in blade length, epidermis cells, and chlorophyll parenchyma in response to the application of $0.208 \mathrm{mM}$ of $\mathrm{BR}_{1}$. Application of a combination of $\mathrm{BR}_{1}$ with $\mathrm{GA}_{3}(0.052$ and 0.072
$\mathrm{mM}$, respectively) also caused a significant increase in blade thickness. This increase is related to an increase in cell size in response to the application of brassinosteroid alone, or in combination with gibberellin. This is in agreement with one of the physiological effects of these growth regulators on cell elongation (Clouse, 1996; Hooley, 1996; Yokota, 1997).

The application of $\mathrm{GA}_{3}(0.2887 \mathrm{mM})$ caused cell divisions in the cortical parenchyma of the petiole abaxial face (Figure 1G), which became slightly circular in comparison with the dorsiventral petiole of control plants (Figure 1F). Stimulation of cell division by brassinosteroids was also reported by Clouse and Zurek (1991) and Iwasaki and Shibaoka (1991).

TABLE 3 - Anatomical parameters of the leaf blade of Tabebuia alba seedlings analyzed 21 days after application of the growth regulators.

\begin{tabular}{|c|c|c|c|c|c|}
\hline \multirow{2}{*}{ Treatments } & \multirow{2}{*}{$\begin{array}{c}\text { Thickness of } \\
\text { the blade }\end{array}$} & \multicolumn{2}{|c|}{ Height of parenchyma } & \multicolumn{2}{|c|}{ Height of epidermis } \\
\hline & & p.p. & 1.p. & ad. & $a b$. \\
\hline Control & $90.9 \mathrm{c}$ & $32.6 \mathrm{~b}$ & $28.6 \mathrm{ab}$ & $14.3 \mathrm{~b}$ & $14.6 \mathrm{~b}$ \\
\hline $\mathrm{BR}_{1} 0.104 \mathrm{mM}$ & $106.9 \mathrm{a}$ & $39.3 \mathrm{a}$ & $31.6 \mathrm{a}$ & $19.3 \mathrm{a}$ & $21.3 \mathrm{a}$ \\
\hline $\mathrm{BR}_{1} 0.208 \mathrm{mM}$ & $96.9 \mathrm{bc}$ & $35.3 \mathrm{ab}$ & $26.3 \mathrm{ab}$ & $20.6 \mathrm{a}$ & $18.6 \mathrm{ab}$ \\
\hline IAA $0.2854 \mathrm{mM}$ & $94.6 \mathrm{bc}$ & $32.2 \mathrm{~b}$ & $27.0 \mathrm{ab}$ & $19.3 \mathrm{a}$ & $15.7 \mathrm{ab}$ \\
\hline IAA $0.5708 \mathrm{mM}$ & $97.9 \mathrm{abc}$ & $39.0 \mathrm{a}$ & $26.3 \mathrm{ab}$ & $17.6 \mathrm{ab}$ & $16.5 \mathrm{ab}$ \\
\hline $\mathrm{GA}_{3} 0.1443 \mathrm{mM}$ & $101.5 \mathrm{ab}$ & $37.6 \mathrm{ab}$ & $27.0 \mathrm{ab}$ & $16.6 \mathrm{ab}$ & $17.0 \mathrm{ab}$ \\
\hline $\mathrm{GA}_{3} 0.2887 \mathrm{mM}$ & $98.2 \mathrm{abc}$ & $35.0 \mathrm{ab}$ & $30.3 \mathrm{ab}$ & $16.3 \mathrm{ab}$ & $17.0 \mathrm{ab}$ \\
\hline $\mathrm{GA}_{3} 0.072 \mathrm{mM}+\mathrm{IAA} 0.1427 \mathrm{mM}$ & $94.2 \mathrm{bc}$ & $40.0 \mathrm{a}$ & $25.6 \mathrm{ab}$ & $17.0 \mathrm{ab}$ & $14.3 \mathrm{~b}$ \\
\hline $\mathrm{GA}_{3} 0.1443 \mathrm{mM}+\mathrm{IAA} 0.2854 \mathrm{mM}$ & $89.9 \mathrm{c}$ & $32.6 \mathrm{~b}$ & $22.6 \mathrm{~b}$ & $18.0 \mathrm{ab}$ & $17.6 \mathrm{ab}$ \\
\hline $\mathrm{GA}_{3} 0.072 \mathrm{mM}+\mathrm{BR}_{1} 0.052 \mathrm{mM}$ & $101.2 \mathrm{ab}$ & $37.0 \mathrm{ab}$ & $26.6 \mathrm{ab}$ & $17.6 \mathrm{ab}$ & $21.3 \mathrm{a}$ \\
\hline $\mathrm{GA}_{3} 0.1443 \mathrm{mM}+\mathrm{BR}_{1} 0.104 \mathrm{mM}$ & $97.6 \mathrm{abc}$ & $37.0 \mathrm{ab}$ & $25.0 \mathrm{ab}$ & $18.3 \mathrm{ab}$ & $17.6 \mathrm{ab}$ \\
\hline
\end{tabular}

Averages followed by the same letter are not significantly different according to the Tukey test $(\mathrm{p} \leq 0.05)$.

palisade parenchyma (p.p.), spongy parenchyma (l.p.), adaxial (ad.) and abaxial (ab.) epidermis. 


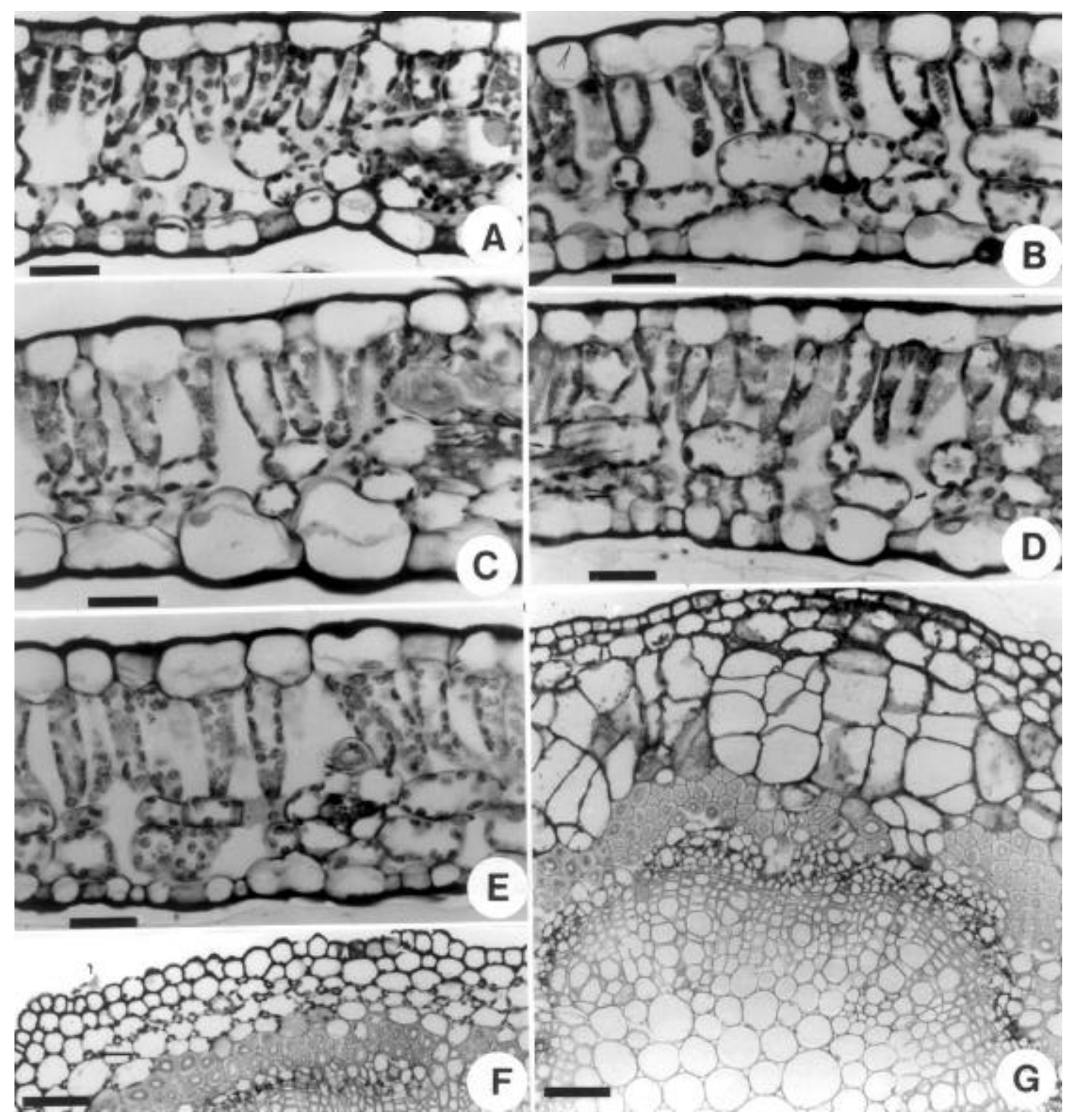

FIGURE 1A-G. Transverse sections of the Tabebuia alba leaf 21 days after application of the growth regulators. A-E: blade. $\mathrm{Bar}=50 \mathrm{~mm}$; F-G: petiole. $\mathrm{Bar}=40 \mathrm{~mm}$. $\mathrm{A}=$ control; $\mathrm{B}=\mathrm{BR}_{1} 0.104 \mathrm{mM} ; \mathrm{C}=$ $\mathrm{BR}_{1} 0.208 \mathrm{mM} ; \mathrm{D}=\mathrm{GA}_{3} 0.072 \mathrm{mM}+\mathrm{BR}_{1} 0.052 \mathrm{mM} ; \mathrm{E}=\mathrm{GA}_{3} 0.1443 \mathrm{mM}+\mathrm{BR}_{1} 0.104 \mathrm{mM} ; \mathrm{F}=$ control; $\mathrm{G}=\mathrm{GA}_{3} 0.2887 \mathrm{mM}$. 
Treatment of Tabebuia alba plants with $\mathrm{BR}_{1}+\mathrm{GA}_{3}$ produced a significant development of lateral buds. Eun et al. (1989) and Fujii et al. (1991) observed that $\mathrm{BR}_{1}$ reduced ABA levels in squash cotyledons (Cucurbita pepo L.) and rice. Therefore, we suggest that application of $\mathrm{GA}_{3}+$ $\mathrm{BR}_{1}$ reduced $\mathrm{ABA}$ level in lateral buds, leading to their development.

The results obtained from petiole and stem growth and anatomical analysis of the leaf blade, hyponasty, and lateral bud development, allowed us to conclude the following:

- There may have been a positive interaction between $\mathrm{GA}_{3}$ and $\mathrm{BR}_{1}$, increasing the $\mathrm{GA}_{3}$ effect,

- There may have been a positive interaction between $\mathrm{GA}_{3}$ and brassinolide, increasing the petiole and stem growth rate of Tabebuia alba seedlings,

- $\mathrm{GA}_{3}$ application caused an increase in petiole and stem growth,

- $\mathrm{GA}_{3}$ combined with $\mathrm{BR}_{1}$ stimulated petiole and stem growth,

- Application of brassinolide alone or combined with GA increased leaf blade thickness, and in the petiole.

- $\mathrm{GA}_{3}$ application stimulated cell division

\section{ACKNOWLEDGMENTS}

We are very grateful to Francisco André Ossamu Tanaka for the preparation of the histological material and to Gustavo Habermann for support in preparing and correcting the manuscript.

\section{REFERENCES}

ARTECA, R.N.; TSAI, D.S.; SCHLAGNHAUFER, C.; MANDAVA, N.B. The effect of brassinosteroid on auxin-induced ethylene production by etiolated mung bean segments. Physiologia Plantarum, 59:539-544, 1983.
CERANA, R.; BONETTI, A.; MARRE, M.T.; ROMANI, G., LADO, P. Effects of a brassinosteroid on growth and electrogenic proton extrusion in Azuki bean epicotyls (Vigna angularis). Physiologia Plantarum, 59:23-27, 1983.

CLOUSE, S.D. Molecular genetic studies confirm the role of brassinosteroids in plant growth and development. Plant Journal, 10:1-8, 1996.

CLOUSE, S.D. \& ZUREK, D. Molecular analysis of brassinolide action in plant growth and development. In: CUTLER, H.G.; YOKOTA, T.; ADAM, G. (Eds.) Brassinosteroids chemistry, bioactivity and applications. Washington, American Chemical Society, 1991. p.122-140.

CLOUSE, S.D.; ZUREK, D.M.; McMORRIS, T.C.; BAKER, M.E. Effect of brassinolide on gene expression in elongating soybean epicotyls. Plant Physiology, 100:1377-1383, 1992.

EUN, J.S.; KURAISHI, S.; SAKURAI, N. Changes in levels of auxin and abscisic acid and the evolution of ethylene in squash hypocotyls after treatment with brassinolide. Plant Cell and Physiology, 30:807-810, 1989.

FUJII, S.; HIRAI, K.; SAKA, H. Growthregulating action of brassinolide in rice plants. In: CUTLER, H.G.; YOKOTA, T.; ADAM, G. (Eds.) Brassinosteroids - chemistry, bioactivity and applications. Washington, American Chemical Society, 1991. p.306-311.

GREGORY, L.E. \& MANDAVA, N.B. The activity and interaction of brassinolide and gibberellic acid in mung bean epicotyls. Physiologia Plantarum, 54:239-243, 1982.

HOOLEY, R. Plant steroid hormones emerge from the dark. Trends Genetic, 12:281-283, 1996.

IWASAKI, T. \& SHIBAOKA, H. Brassinosteroids act as regulators of tracheary-element differentiation in isolated Zinnia mesophyll cells. Plant Cell and Physiology, 32:10071014, 1991. 
KATSUMI, M. Interaction of a brassinosteroid with IAA and $\mathrm{GA}_{3}$ in the elongation of cucumber hypocotyl sections. Plant Cell and Physiology, 26:615-625, 1985.

KATSUMI, M. Physiological modes of brassinolide action in cucumber hypocotyl growth. In: CUTLER, H.G.; YOKOTA, T.; ADAM, G. (Eds.) Brassinosteroids - chemistry, bioactivity and applications. Washington, American Chemical Society, 1991. p.246-254.

MANDAVA, N.B. Plant growth-promoting brassinosteroids. Annual Review of Plant Physiology and Plant Molecular Biology, 39:23-52, 1988.

MAYUMI, K. \& SHIBAOKA, H. A possible double role of brassinolide in the reorientation of cortical microtubules in the epidermal cells of Azuki bean epicotyls. Plant Cell and Physiology, 36:173-181, 1995.

NOMURA, T. et al. Blockage of brassinosteroid biosynthesis and sensitivity causes dwarfism in garden pea. Plant Physiology, 113:31-37, 1997.

POTTER, I. \& FRY, S.C. Changes in xyloglucan endotransglycosylase (XET) activity during hormone-induced growth in lettuce and cucumber hypocotyls and spinach cell suspension cultures. Journal Experimental of Botany 45:1703-1710, 1994.

ROBERTS, J.A. \& HOOLEY, R. Plant growth regulators. New York, Chapman and Hall, 1988. 190p.

SASSE, J.M. Brassinolide - induced elongation and auxin. Physiologia Plantarum, 80:401408, 1990.

SMITH, R.C.; MATTHEWS, P.R.; SCHUNMANN, P.H.D.; CHANDLER, P.M. The regulation of leaf elongation and xyloglucan endotransglycosylase by gibberellin in "Himalaya" barley (Hordeum vulgare L.). Journal Experimental of Botany, 47:1395-1404, 1996.
TAKENO, K. \& PHARIS, R.P. Brassinosteroidinduced bending of leaf lamina of dwarf rice seedlings and auxin-mediated phenomenon. Plant Cell and Physiology, 23:1275-1281, 1982.

VAÑKOVÁ, R.; HSIAO, K.C.; BORNMAN, C.; GAUDINOVÁ, A. Effect of synthetic cytokinins on levels of endogenous cytokinins and respiration patterns of Beta vulgaris cells in suspension. Plant Growth Regulators, 10:197-199, 1991.

VAÑKOVÁ, R.; GAUDINOVÁ, A.; KAMÍNEK, M.; EDER, J. The effect of interaction of synthetic cytokinin and auxin on production of natural cytokinins by immobilized tobacco cells. In: KAMÍNEK, M.; MOK, D.W.S.; ZAZIMAlOVÁ, E. (Eds.) Physiology and biochemistry of cytokinins in plants. The Hague, SPB Acad. Publishing, 1992. p.47-51.

YOKOTA, T. The structure, biosynthesis and function of brassinosteroids. Trends Plant Science, 2:137-143, 1997.

YOKOTA, T. \& TAKAHASHI, N. Chemistry, physiology and agricultural application of brassinolide and related steroids. In: BOPP, $\mathrm{M}$. (Ed.) Plant Growth Substances. Berlin, Springer-Verlag, 1985. p.129-138.

YOPP, J.H.; MANDAVA, N.B.; SASSE, J.M. Brassinolide, a growth-promoting steroidal lactone. I. Activity in selected auxin bioassays. Physiologia Plantarum, 53:445-452, 1981.

XU, W.; PURUGGANAN, M.M.; POLISENSKY, D.H.; ANTOSIEWICZ, D.M.; FRY, S.C., BRAAM, J. Arabidopsis TCH4, regulated by hormones and the environment, encodes a xyloglucan endotransglycosylase. Plant Cell, 7:1555-1567, 1995.

ZUREK, D.M.; RAYLE, D.L.; McMORRIS, T.C.; CLOUSE, S.D. Investigation of gene experssion, growth kinetics, and wall extensibility during brassinoesteroid-regulated stem elongation. Plant Physiology, 104:505513, 1994. 